\title{
Resistance of Dermo in eastern oysters, Crassostrea virginica (Gmelin), of North Carolina but not Chesapeake Bay Heritage
}

\author{
Bonnie L Brown', Arthur J Butt ${ }^{2}$, Stephen W Shelton ${ }^{3}$, Donald Meritt ${ }^{4}$ \& Kennedy T Paynter ${ }^{5,6}$ \\ ${ }^{1}$ Department of Biology and Center for Environmental Studies, Virginia Commonwealth University, Richmond, VA, USA \\ ${ }^{2}$ EcoGen Inc., Richmond, VA, USA \\ ${ }^{3}$ Safety Harbour, FL, USA \\ ${ }^{4}$ University of Maryland Center for Environmental Science, Horn Point Laboratory, Cambridge, MD, USA \\ ${ }^{5}$ Chesapeake Biological Laboratory, University of Maryland Center for Environmental Science, Solomons, MD, USA \\ ${ }^{6}$ Department of Biology, University of Maryland, College Park, MD, USA
}

Correspondence: B L Brown,VCU Ecological Genetics Laboratory, PO Box 842012, Richmond,VA 23284, USA. E-mail: blbrown@vcu.edu

\begin{abstract}
Growth, intensity of Perkinsus marinus (Levine) infection, and survival of synchronously spawned North Carolina (NC) and Chesapeake Bay-heritage (CB) oysters, Crassostrea virginica (Gmelin) were evaluated under standard tray culture conditions at several sites in both regions (Wye River, Maryland; Mobjack Bay, Virginia; Pamlico River, NC and Bogue Banks, NC). Infection prevalence reached $100 \%$ in oysters held at all high- and moderate-salinity sites, at which time the $\mathrm{CB}$ strain ceased to grow. Shortly after growth ceased, CB oysters exhibited mortality that rapidly progressed to $100 \%$. Unlike the CB strain, growth continued in the NC strain despite high $P$. marinus prevalence. When mortality did occur in the NC strain, at a reduced rate of $37-40 \%$, it was associated with higher intensity of $P$. marinus than the infection intensity correlated with death of CB oysters. At the low-salinity site in NC, P. marinus infection persisted at low weighted prevalence throughout the latter portion of the culture period but was not associated with mortality of either strain. These trends in growth and disease resistance for the two strains demonstrate that aquaculture performance is related to the level of disease resistance in oyster strains, salinity of water in growing areas and virulence of P. marinus.
\end{abstract}

Keywords: growth, disease, resistance, mortality, Crassostrea virginica (Gmelin)

\section{Introduction}

The continuing decline of wild oyster stocks because of overharvest and disease has stimulated considerable interest in the potential for commercial oyster culture in the United States mid-Atlantic region. Brown, Butt, Shelton and Paynter (1998) reported the performance of two strains of the native Eastern oyster at several sites along the mid-Atlantic coast of North America and concluded that innate differences between the strains as well as variability in virulence of Perkinsus marinus (Levine), the causative agent of Dermo disease, among the culture sites affected oyster production. They also observed that a strain derived from wild North Carolina (NC) broodstock exhibited significant tolerance of the P. marinus parasite when cultured in Chesapeake Bay (CB). Subsequently, a number of teams undertook selective breeding programs that resulted in strains with increased resistance to Dermo (Ragone Calvo, Calvo \& Burreson 2003). Nevertheless, expansion of culture enterprises for the native oyster, Crassostrea virginica (Gmelin), in the mid-Atlantic continues to be hindered in part by the lack of disease-resistant strains and in part because of the lack of information regarding expected production rates of different strains of the native oyster in the wide variety of habitats typical of the estuaries in this region.

To further examine this phenomenon, production traits for two different $C$. virginica strains (one from upper CB, Maryland and one from Pamlico Sound, 
NC) were evaluated between September 1992 and August 1994 using standard tray-culture conditions at two sites in CB and two sites in Pamlico Sound. The cultivation scenario was designed to provide information on major factors affecting successful cultivation of commercial quantities of two Eastern oyster strains and to enhance knowledge regarding the physiological effects of disease on these native strains when held outside their familial environments. The objectives of the study were to evaluate and compare the production characteristics of the both strains in both regions and the response of both strains (in terms of condition, growth and mortality) to infection by $P$. marinus.

\section{Materials and methods}

\section{Oyster strains}

Two wild oyster populations that are typically sampled for spawning stock were chosen for production of experimental families. Separate samples of approximately 100 adult wild oysters each were obtained from the Cape Lookout area of NCs Pamlico Sound (NC), where waters are typically $30 \mathrm{gL}^{-1}$, and from upper CB near Annapolis, Maryland (CB), where salinity is typically $0-5 \mathrm{~g} \mathrm{~L}^{-1}$. Cultchless oyster spat were produced using traditional hatchery methods (Paynter \& DiMichele 1990). Both groups were synchronously spawned in May 1992 at the Horn Point Environmental Laboratory hatchery, Cambridge, Maryland. Spat were maintained at that location in flow-through upweller systems with unfiltered seawater until they were $8 \mathrm{~mm}$ in shell height and subsequently transferred to floating trays of small mesh size ( $3 \mathrm{~mm}$ diamond mesh). Prior to deployment at the four culture sites, whole body preparations of 25 spat samples from both strains were tested using RFTM, the fluid thioglycolate method of Ray (1954), to ensure they were negative for presence of $P$. marinus infection.

\section{Study areas}

In September 1992, both cohorts were split into quarters and introduced into floating replicate containers side-by-side at four sites representing two separate estuarine bodies of water (CB and Pamlico Sound) and several different salinity regimes typical of midAtlantic ecosystems (Fig. 1). Study sites were selected on the basis of environmental quality, salinity and ease of access. The two sites located in CB were Mobjack Bay, where salinity averaged $20 \mathrm{~g} \mathrm{~L}^{-1}$ (moderate) and Wye River, where salinity averaged $10 \mathrm{~g} \mathrm{~L}^{-1}$ (low). The two sites in Pamlico Sound were Bogue Banks, where salinity averaged $30 \mathrm{~g} \mathrm{~L}^{-1}$ (high), and Pamlico River with average salinity of $10 \mathrm{~g} \mathrm{~L}^{-1}$ (low).

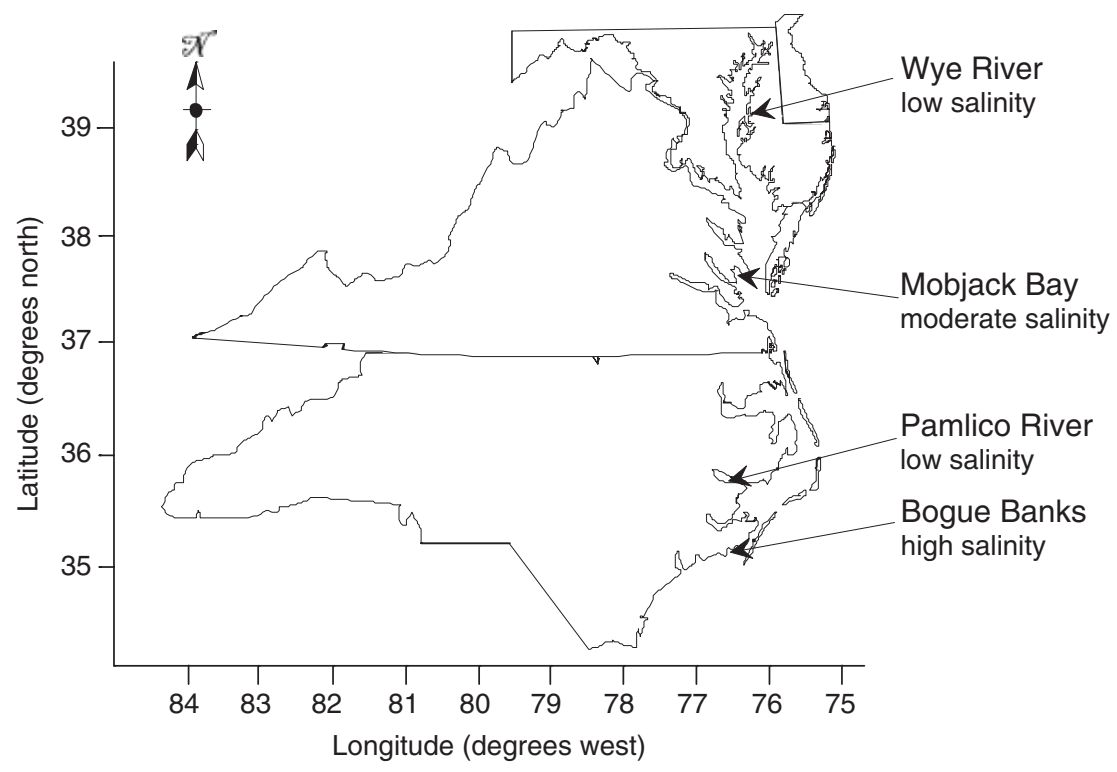

Figure 1 Map of the mid-Atlantic area of United States showing sites selected for culture and comparison of Eastern oyster, Crassostrea virginica (Gmelin), growth, disease resistance and mortality. Sites of cultivation in Chesapeake Bay were Wye River and Mobjack Bay. Sites of cultivation in Pamlico Sound were Pamlico River and Bogue Banks. 


\section{Culture containers}

To limit exposure to predators, siltation and other consequences of benthic habitation, floating trays were used as culture containers. As outlined by Paynter and Burreson (1991), each tray consisted of a wooden frame approximately $91 \mathrm{~cm} \times 61 \mathrm{~cm}$ with polyethylene mesh (19 mm diamond mesh) folded into a rectangular box that hung below the wooden frame and was secured to the frame along the edges. The resulting mesh box was $91 \mathrm{~cm}$ long $\times 61 \mathrm{~cm}$ wide $\times 20 \mathrm{~cm}$ deep. A $91 \mathrm{~cm} \times 61 \mathrm{~cm}$ panel of chlorofluorocarbon-free extruded styrofoam wedged underneath the wooden frame was used to keep the tray afloat. Trays were originally equipped with $6 \mathrm{~mm}$ liners and as oysters grew, the liners were removed and/or replaced with new liners of successively larger mesh. The final culture phase was in the outer $19 \mathrm{~mm}$ diagonal mesh size.

\section{Data collection}

Oyster spat averaging $12 \mathrm{~mm}(\mathrm{NC})$ and $11 \mathrm{~mm}(\mathrm{CB})$ shell height were placed in floating trays (approximately 3000 oysters per tray) at the two NC sites in September 1992 and at the two CB sites in November 1992. At the NC sites, both strains were held in replicate trays to facilitate estimation of environmental and sampling variability. Over time as the trays became crowded, groups were split into additional trays. In this way, densities were considered to be non-growth limiting at all stages of the study. At all times, the different cohorts held at the same site were kept in separate trays.

Hydrological parameters (salinity and temperature) were recorded for each site monthly throughout the study period beginning in October 1992. At these times, additional measurements were made for shell height, total mortality was quantified in each tray, and samples were collected for determination of prevalence and intensity of $P$. marinus infection. Average shell height of each group was estimated by collecting a single haphazard grab of 25-50 oysters from each tray and measuring shell height to the nearest millimetre from the hinge to the ventral shell margin for all individuals in the grab (Galtsoff 1964). Sampling continued through August 1994, when the majority of oysters had reached harvestable size of $76 \mathrm{~mm}$.

The level of infection with P. marinus was assayed during most months in samples of 25 oysters from each strain at each site using RFTM, (Ray 1954). In- fection intensity was scored as: negative $=0$, light $=1$, moderate $=3$ and heavy $=5$, according to Mackin, Owen and Collier (1950). Weighted infection prevalence (WP) was calculated for each tray as the mean of the individual infection intensities of the oysters sampled from that tray. Because mortalities typically associated with Haplosporidium nelsoni (MSX) infection were not observed (i.e., mortality of smaller oysters early in the summer), the level of $H$. nelsoni infection with was not evaluated during this study.

\section{Statistical analyses}

Differences in shell height, mortality and weighted infection prevalence among strains of $P$. marinus was assessed by one- and two-way repeated measures analysis of variance, linear regression, Pearson's product moment correlation, Spearman's rank order correlation and non-parametric tests. Where data failed to conform to normality assumptions or variances were not homogenous, raw data were transformed. Specifically, percent mortality and weighted P. marinus prevalence were transformed by the addition of 0.5 , and growth rate (calculated as shell height at time $t_{2}$ minus shell height at time $t_{1}$ ) was natural log transformed.

\section{Results}

\section{Hydrology}

Physical hydrology of the $\mathrm{CB}$ and Pamlico regions was similar but not identical. Salinities at CB sites were less variable than those encountered at Pamlico Sound sites. Salinities in $\mathrm{CB}$ ranged from 8 to $12 \mathrm{~g} \mathrm{~L}^{-1}$ (Wye River-low) and from 16 to $20 \mathrm{~g} \mathrm{~L}^{-1}$ in Mobjack Bay (moderate). In NC, salinities ranging from 1 to $18 \mathrm{~g} \mathrm{~L}^{-1}$ were recorded at the Pamlico River site (low), whereas Bogue Banks (high) ranged from 15 to $34 \mathrm{~g} \mathrm{~L}^{-1}$. Surface water temperatures recorded at both NC sites were virtually identical on each sampling date, ranging from 5 to $33^{\circ} \mathrm{C}$, during the study period, whereas $\mathrm{CB}$ surface temperatures were lower, ranging from -1 to $29^{\circ} \mathrm{C}$.

\section{Growth}

Significant growth differences were observed between groups cultivated in CB and Pamlico Sound. At the low salinity Pamlico Sound site, the CB strain 
Table 1 Final mean shell height \pm SE, maximum growth rate encountered, cumulative percentage mortality and weighted prevalence of Perkinsus marinus (Levine) at the onset of mortality for two Eastern oyster strains, Crassostrea virginica (Gmelin), held at four sites during a 24-month field trial

\begin{tabular}{|c|c|c|c|c|c|c|c|c|}
\hline & \multicolumn{4}{|c|}{ NC strain } & \multicolumn{4}{|c|}{ CB strain } \\
\hline & \multicolumn{2}{|c|}{$\begin{array}{l}\text { Chesapeake } \\
\text { Bay }\left(\mathrm{g} \mathrm{L}^{-1}\right)\end{array}$} & \multicolumn{2}{|c|}{$\begin{array}{l}\text { Pamlico } \\
\text { Sound }\left(\mathrm{g} \mathrm{L}^{-1}\right)\end{array}$} & \multicolumn{2}{|c|}{$\begin{array}{l}\text { Chesapeake } \\
\text { Bay }\left(\mathrm{g} \mathrm{L}^{-1}\right)\end{array}$} & \multicolumn{2}{|c|}{$\begin{array}{l}\text { Pamlico } \\
\text { Sound }\left(\mathrm{g} \mathrm{L}^{-1}\right)\end{array}$} \\
\hline & 10 & 20 & 10 & 30 & 10 & 20 & 10 & 30 \\
\hline Shell height (mm) & $70 \pm 2$ & $95 \pm 2$ & $70 \pm 1$ & $93 \pm 1$ & $70 \pm 2$ & $65 \pm 2$ & $84 \pm 1$ & $63 \pm 2$ \\
\hline $\begin{array}{l}\text { Growth rate (maximum } \\
\text { mm month }{ }^{-1} \text { ) }\end{array}$ & 10 & 13 & 16 & 18 & 13 & 15 & 12 & 10 \\
\hline Mortality (cumulative \%) & 4 & 40 & 13 & 47 & 4 & 100 & 15 & 100 \\
\hline P. marinus (weighted prevalence) & 0.5 & 3.3 & 1.5 & $1.6^{*}$ & 0.6 & $3.3^{*}$ & 1.5 & $2.4^{*}$ \\
\hline $\begin{array}{l}\text { Correlation coefficient for weighted } \\
\text { prevalence vs. mortality }\end{array}$ & $\begin{array}{c}0.045 \\
(0.863)\end{array}$ & $\begin{array}{l}0.386 \\
(0.150)\end{array}$ & $\begin{array}{r}-0.092 \\
(0.686)\end{array}$ & $\begin{array}{c}0.575 \\
(0.008)\end{array}$ & $\begin{array}{c}0.247 \\
(0.367)\end{array}$ & $\begin{array}{l}0.546 \\
(0.041)\end{array}$ & $\begin{array}{r}-0.002 \\
(0.989)\end{array}$ & $\begin{array}{r}0.818 \\
(0.000)\end{array}$ \\
\hline
\end{tabular}

Weighted prevalence entries with an asterisk ${ }^{* *}$ indicate that level of P. marinus infection was significantly correlated with mortality for that strain at that site. Correlation coefficients and their corrected P-values are shown in the bottom row.

grew significantly larger than the NC strain (Table 1, $P<0.001)$ during the study period. Seasonal growth patterns of the two strains were otherwise similar at that site (Fig. 2). At the low-salinity $\mathrm{CB}$ site, the observed growth rate of $\mathrm{CB}$ oysters was greater than for $\mathrm{NC}$ oysters $(P<0.001)$, however, both strains reached similar sizes by the end of the culture period. At the high-salinity Pamlico Sound site, growth rates of the two strains were similar before the onset of heavy P. marinus infection (Fig. 2; circa July 1993) after which, the NC strain continued growing while growth ceased in the CB strain. Following onset of disease at that site, the strains experienced significantly different levels of mortality $(P=0.001)$; culminating at $100 \%$ for the CB strain (at 15 months) and $47 \%$ for the NC strain (at 24 months). Patterns of growth- and disease-induced mortality for both strains at the moderate-salinity CB site were similar to patterns observed in Pamlico Sound (Figs 2 and 3).

\section{Disease}

Both the $\mathrm{CB}$ and NC strains acquired P. marinus infections at similar times and intensities at all four sites (Figs 3 and 4). Oysters raised at both low-salinity sites experienced low infection intensities and low mortality throughout the study. Infection with P. marinus was acquired earlier and intensified more quickly in oysters held in moderate salinity (Mobjack Bay) than those held at the low salinity Wye River site. During the times when both $\mathrm{NC}$ and $\mathrm{CB}$ strains were present at a site, no significant difference was observed between $P$. marinus infection level of these strains held at low salinity in $\mathrm{CB}(P=0.244)$, at low salinity in Pamlico Sound $(P=0.950)$, moderate salinity $\mathrm{CB}$ area $(P=0.516)$ and high salinity Pamlico Sound $(P=0.217)$.

\section{Mortality}

Initial post-introduction (i.e., non-disease related) mortality at all sites and for both strains was approximately $1 \%$. Subsequent mortality because of predators, fouling and disease averaged approximately $1 \%$ per month. Although no significant disease-induced mortality was observed at the low-salinity sites for either of the oyster strains, significant differences were observed in disease-related mortality between the two strains at the higher-salinity sites (Table 1, Figs 3 and 4). Specifically, CB oysters held at the two higher-salinity sites died en masse beginning in September 1993, most likely from heavy P. marinus infections, which reached weighted infection prevalences of nearly 3.0 (Fig. 3). Conversely, despite slightly elevated summertime mortality at the low-salinity $\mathrm{CB}$ site, NC oysters did not experience mass mortality at any site as did the CB strain held at both highersalinity sites (Fig. 4).

In $\mathrm{CB}$, mortality of the NC strain began in July but continued only through the fall months, ceasing during the winter months (November 1992-March 1993), then resuming again in late spring (April 1993). The portion of the NC cohort reared at the high salinity Pamlico Sound site exhibited a relatively low but continual rate of mortality, commencing in July 1992 and 


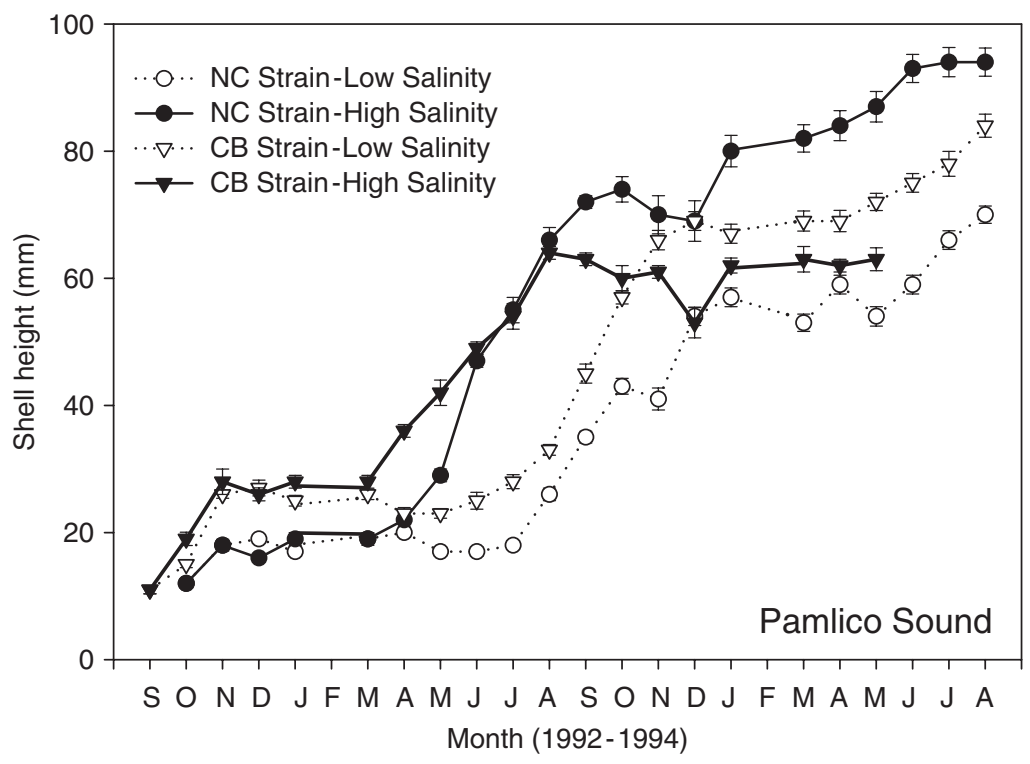

Figure 2 Average shell height \pm SE (in millimeters) of two oyster, Crassostrea virginica (Gmelin), strains held at four sites. Heritage of the oyster strains was North Carolina (NC) and Chesapeake Bay (CB). In CB, the low-salinity site was Wye River, and the moderate-salinity site was Mobjack Bay. In Pamlico Sound, the low-salinity site was Pamlico River, and the high-salinity site was Bogue Banks. Locations of the four sites are shown in Fig. 1.

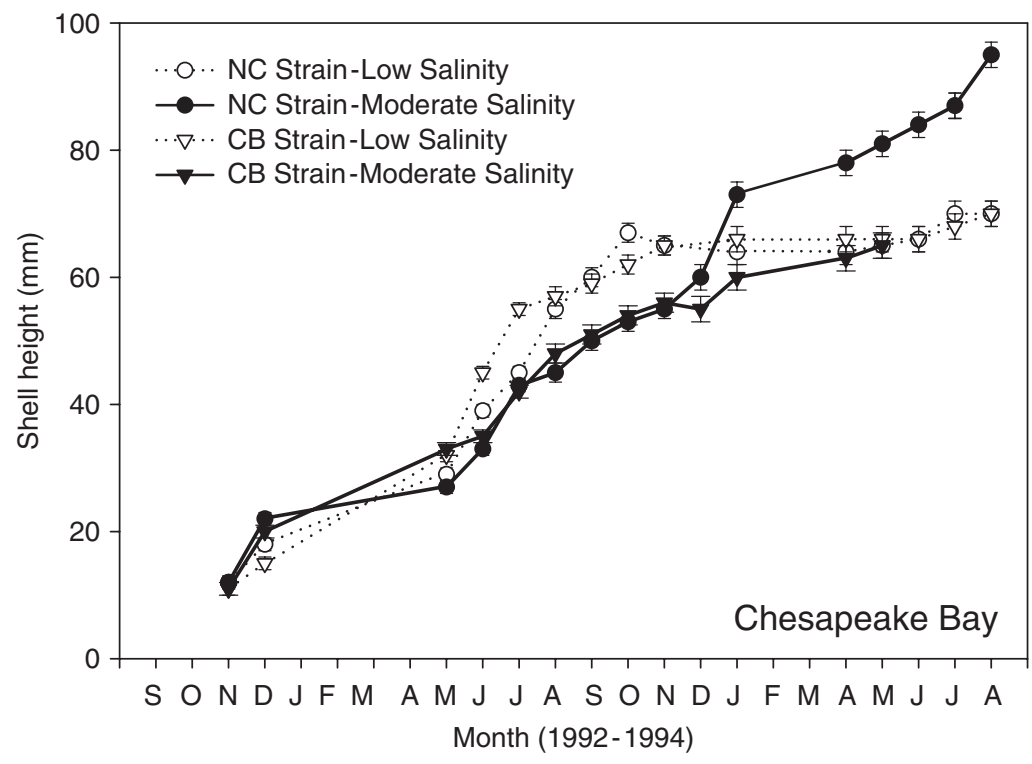

extending through the duration of the study to a final cumulative mortality of $47 \%$. Cumulative mortality for the NC cohorts held at the low-salinity Pamlico Sound site increased at a rate similar to those held at high salinity but terminated in the winter (December 1992) and did not resume during the study period. Cumulative mortality over the period of observation for the NC strain was $4 \%$ and $13 \%$ at the low-salinity sites in $\mathrm{CB}$ and Pamlico Sound respectively. Cumulative mortality for the NC oysters was $40 \%$ and $47 \%$ at the higher-salinity $\mathrm{CB}$ and Pamlico Sound sites, respectively. Linear regression of transformed data indicated a significant relationship between mortal- ity and intensity of P. marinus infection only at the higher-salinity sites (Table 1).

\section{Discussion}

The most notable aspect of the interaction among growth, disease and mortality was the continued growth and survival of the NC strain despite heavy $P$. marinus infection at the higher-salinity sites in both regions while, in contrast, the $\mathrm{CB}$ strain oysters at those sites ceased growing and died once infected. Both strains of oysters raised in low salinity eventually acquired and maintained relatively low levels 

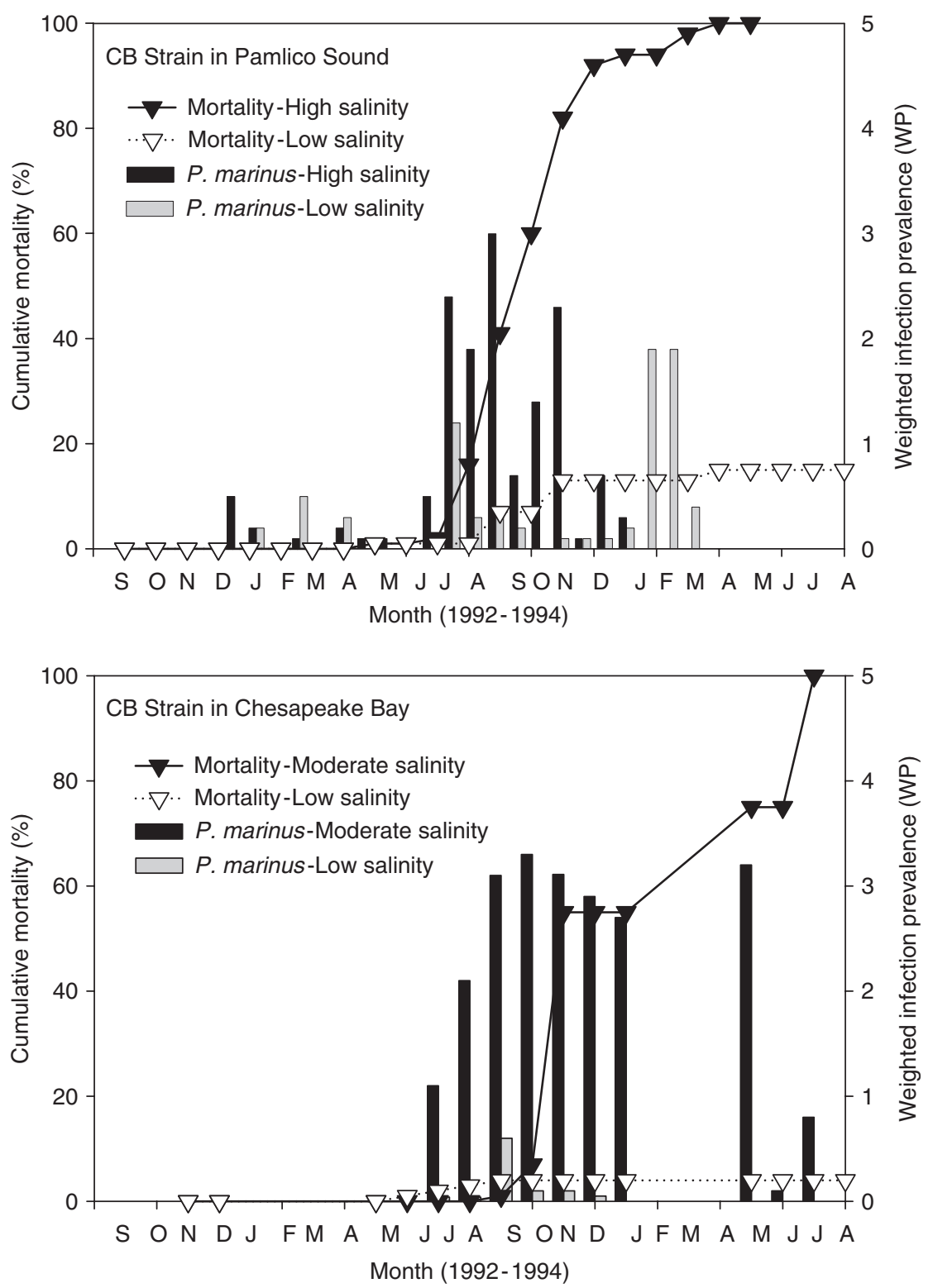

Figure 3 Weighted prevalence of Perkinsus marinus (Levine) and mortality for the Chesapeake Bay (CB) oyster strain, Crassostrea virginica (Gmelin), held at low- and high-salinity sites in Pamlico Sound and at low- and moderate-salinity sites in Chesapeake Bay. Descriptions of oyster heritage and of cultivation sites are listed in Figs 1 and 2.

of infection that were not significantly correlated with growth or mortality. At the higher-salinity sites, both NC and CB oysters acquired the parasite early and the burdens intensified rapidly over the first summer, from WP = 0 in May 1993 to WP > 3 by October 1993. However, while these heavy parasite burdens were associated with $100 \%$ mortality in the CB oysters in both salinity regimes, only 20-30\% mortality was observed during the first summer in the $\mathrm{NC}$ oysters. Thus, the NC strain exhibited a considerable degree of resistance to $P$. marinus infection.

A variety of possible differences between the $\mathrm{CB}$ and NC oyster strains used in this study could account for the observation that the $\mathrm{CB}$ group had a more severe response to $P$. marinus infection than the NC group. Although substantial genetic distinctions have not been demonstrated among native mid-Atlantic Eastern oyster populations (Buroker 

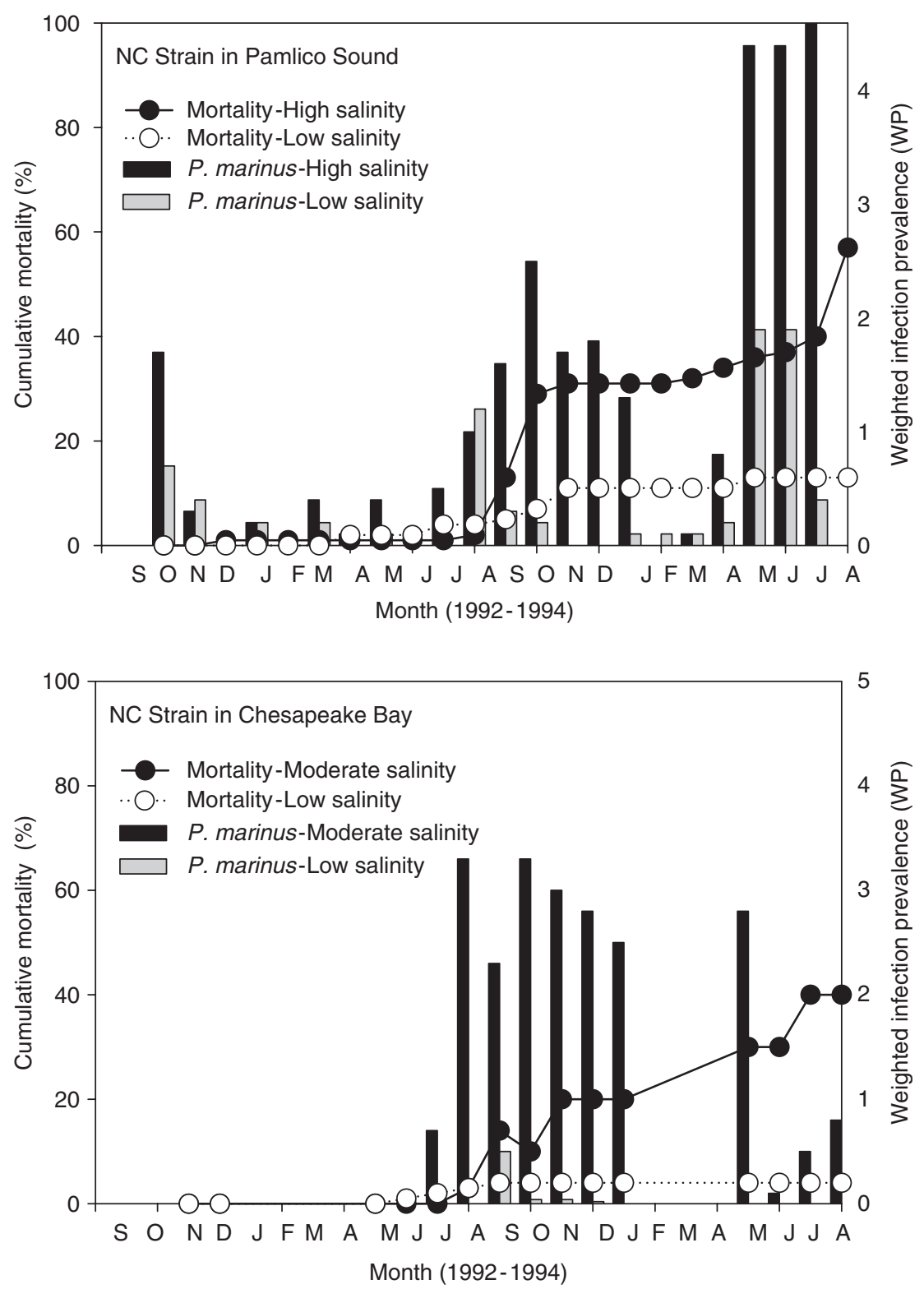

Figure 4 Weighted prevalence of Perkinsus marinus (Levine) and mortality for the North Carolina (NC) oyster strain, Crassostrea virginica (Gmelin), held at low- and high-salinity sites in Pamlico Sound and at low- and moderate-salinity sites in Chesapeake Bay. Descriptions of oyster heritage and of cultivation sites are listed in Figs 1 and 2.

1984; Reeb \& Avise 1990; Brown \& Paynter 1991), heretofore undetected genetic differences may exist between these groups of oysters that translate to enhanced resistance of $P$. marinus infection of $\mathrm{NC}$ oysters. For instance, it is likely that NC oysters have been subject to natural selection for resistance to $P$. marinus over the generations as the parasite was introduced and are therefore adapted to local disease pressure. Standard population genetic survey methods would not likely uncover such differences be- tween NC and CB oysters. Conversely, the NC oysters could simply be more tolerant of P. marinus infections as a result of greater genetic diversity. In either case, enhanced resistance of the NC strain is indicated by the low mortalities experienced by the $\mathrm{NC}$ strain when reared in $\mathrm{CB}$, whereas the $\mathrm{CB}$ oysters at the same site acquired heavy infections and died.

The NC oysters acquired higher WP at the moderate-salinity $\mathrm{CB}$ site than their siblings raised in highsalinity Pamlico Sound waters. This observation 
suggests that further ecological interactions are important, namely that $P$. marinus in $\mathrm{CB}$ is more virulent or that infection pressures are much higher in $\mathrm{CB}$ than in Pamlico Sound. Recent laboratory-based disease challenges by Bushek and Allen (1996) have demonstrated differences among $P$. marinus strains collected from different geographic regions of the Atlantic and Gulf coasts. Indeed, differences in $P$. marinus prevalence (Paynter 1996) and virulence (Bushek \& Allen 1996) also are likely factors in this study. For example, P. marinus infections in Pamlico Sound never reached the intensities recorded in CB. In Pamlico Sound, infections at low salinity rose to a peak (WP < 1.0) in July 1992 and then declined during the fall and winter months. Conversely, in high salinity, more intense infections were acquired rapidly ( $\mathrm{WP}=1.0$ within 30 days), but the infections did not intensify to the level observed at the moderate-salinity site in CB. Disease in NC oysters raised in high-salinity waters of Pamlico Sound remained relatively stable around $\mathrm{WP}=1.0-1.6$ from May through January. Although temperature and salinity are thought to be the two most potent environmental stimulants of Perkinsus virulence in some areas (Andrews 1988), the findings of this study appear to agree with the observation of Coen, Wenner, Knott, Stender, Hadley, Bobo and Richardson (1997) that coastal oyster populations of the southeast and Gulf coasts suffer less annual mortality related to $P$. marinus than occurs in $\mathrm{CB}$ oyster populations.

\section{Conclusion}

This study illustrates how interactions among environment, genetics, virulence and physiological response to infection are manifest as differences in disease dynamics. Oysters are predominantly distributed along the southern Atlantic coast as intertidal populations found in tidal creeks, shallow inlets, and marshy areas and at the margins of tidal estuaries and bays. By comparison, few intertidal populations of oysters presently exist in $\mathrm{CB}$, although they were reported to be highly abundant before commercial exploitation (pre-1850) (Brooks \& Paynter 1996). The current $\mathrm{CB}$ oyster population is characterized by relict subtidal low density subpopulations located on the remnants of natural bars. Furthermore, the destruction of Chesapeake oyster habitat (Rothschild, Ault, Goulletquer \& Heral 1994) and degradation of water quality over the last 40 years may have led to changes in the parasite/oyster relationship that favour the parasite in CB today. Studies in the Gulf of Mexico support this scenario (Mackin \& Hopkins 1961).

Data from this study imply that unlike the $\mathrm{CB}$ strain, the $\mathrm{NC}$ strain of $C$. virginica is at least partially resistant to Dermo disease as a result of natural selection. The disease resistance of the NC strain makes it an excellent candidate for selective breeding programs that would focus on both disease resistance and salinity tolerance, and makes it a superior choice for short-term commercial cultivation in higher-salinity waters of the Bay. Conversely, there would be little advantage at this time to cultivating this wild strain in lower-salinity regions of the Bay, because of the slightly elevated level of summer mortality in lower-salinity regions as compared with that of the native $\mathrm{CB}$ strain and the fact that the extant $\mathrm{CB}$ strain demonstrates a growth rate superior to the NC strain at low salinity. Information useful for the future application of this strain would include molecular genetic maps of the differences between the NC strain and other strains, coupled with a more accurate characterization of differences, if any, among the $P$. marinus parasites of both regions and the mechanics and physiological response to P. marinus infection.

\section{Acknowledgments}

This study was funded in part by discretionary funds from North Carolina Sea Grant, Chesapeake Scientific Investigations Foundation, Virginia Commonwealth University and World's End Aquaculture. We thank X. Guo for comments on an earlier version of the manuscript, K. Kester for assistance with statistical analyses, both the North Carolina Division of Marine Fisheries and E. Burreson at Virginia Institute of Marine Science for oyster disease analyses, and M. Mallonee for assisting in the field. Test sites in North Carolina and assistance with monthly measurements were provided by M. Hooper and family, G. Daniel, S. Kemp and the North Carolina Aquarium, D. Bova, A. McGinty and G. Beckman of the North Carolina Aquaculture Facility. M. Marshall assisted with obtaining the necessary permits in North Carolina.

\section{References}

Andrews J.D. (1988) Epizootiology of the disease caused by the oyster pathogen, Perkinsus marinus and its effects on the oyster industry. In: Disease Processes in Marine Bivalve Molluscs (ed. by W.S. Fisher), pp. 47-63. American Fisheries Society Special Publication No. 18, Bethesda, MD, USA. 
Brooks W.K. \& Paynter K.T. (1996) The Oyster. Johns Hopkins University Press, Baltimore, MD, USA.

Brown B.L. \& Paynter K.T. (1991) Mitochondrial DNA analysis of native and selectively inbred Chesapeake Bay oysters (Crassostrea virginica). Marine Biology 110, 343-352.

Brown B.L., Butt A.J., Shelton S.W. \& Paynter K.T. (1998) Growth and mortality of North Carolina-heritage oysters, Crassostrea virginica, in North Carolina and in Chesapeake Bay. Journal of Applied Aquaculture 8, 25-39.

Buroker N. (1984) Gene flow in mainland and insular populations of Crassostrea (Mollusca). Biology Bulletin 166, 550-557.

Bushek D. \& Allen S.K. Jr (1996) Races of Perkinsus marinus. Journal of Shellfish Research 15, 103-107.

Coen L.D., Wenner E.L., Knott D.M., Stender B., Hadley N.H., Bobo M.Y. \& Richardson D.L. (1997) Intertidal oyster reef habitat assessment and restoration: evaluating habitat use, development, and function. Journal of Shellfish Research 16, 262.

Galtsoff P.S. (1964) The American oyster. Fisheries Bulletin 64, 1-480.

Mackin J.G. \& Hopkins S.H. (1961) Studies on oyster mortality in relation to natural environments and to oil fields in Louisiana. Publication of the University of Texas Institute of Marine Science 7, 3-131.

Mackin J.G., Owen H.M. \& Collier A. (1950) Preliminary note on the occurrence of a new protistan parasite, Dermocys- tidium marinum n. sp. in Crassostrea virginica (Gmelin). Science 111, 328-329.

Paynter K.T. (1996) The effects of Perkinsus marinus infection on various physiologies of the Eastern oyster, Crassostrea virginica. Journal of Shellfish Research 15, 119-125.

Paynter K.T. \& Burreson E.M. (1991) Effects of Perkinsus marinus infection in the Eastern oyster, Crassostrea virginica: II. Disease development and impact on growth at different salinities. Journal of Shellfish Research 10,425-431.

Paynter K.T. \& DiMichele L. (1990) Growth of tray cultured oysters (Crassostrea virginica Gmelin) in the Chesapeake Bay. Aquaculture 87, 289-298.

Ragone Calvo L.M., Calvo G.W., \& Burreson E.M. (2003) Dual disease resistance in a selectively-bred eastern oyster, Crassostrea virginica, strain tested in Chesapeake Bay. Aquaculture 220, 69-87.

Ray S.M. (1954) Biological Studies of Dermocystidium marinum, A Fungus Parasite of Oysters. Rice Institute Pamphlet, Houston, TX, USA.

Reeb C.A. \& Avise J.C. (1990) A genetic discontinuity in a continuously distributed species: mitochondrial DNA in the American oyster, Crassostrea virginica. Genetics 124, 397-406.

Rothschild B.J., Ault J.S., Goulletquer P. \& Heral M. (1994) Decline of the Chesapeake Bay oyster population: a century of habitat destruction and overfishing. Marine Ecology Progress Series 111, 29-39. 